\title{
Artikel
}

\section{De informatieplicht voor de franchisegever naar Nederlands recht}

\author{
Beschouwingen naar aanleiding van het Albert Heijn-arrest
}

Mr. dr. S.A. Kruisinga en mr. M.I. Nijenhof-Wolters*

\section{Inleiding}

De franchiseovereenkomst is door de Nederlandse wetgever onzes inziens de afgelopen jaren wat stiefmoederlijk behandeld. Waar de branche er zelf voor heeft gezorgd dat er op nationaal niveau een Nederlandse Franchise Code (NFC) bestaat, in Europa de zogenoemde Europese Erecode inzake Franchising (EEF) tot stand is gebracht en, bijvoorbeeld, België speciale wetgeving heeft die van toepassing is op de franchiseovereenkomst, doet de Nederlandse wetgever een dappere poging om ook voor Nederland een regelgevend kader te ontwerpen voor de franchiseovereenkomst. Ook andere landen, zoals Frankrijk, kennen speciale regelgeving voor de franchiseovereenkomst. In veel gevallen bevat deze franchisewetgeving onder meer een verplichting voor de franchisegever om, voorafgaand aan de totstandkoming van de franchiseovereenkomst, specifieke informatie te verstrekken an de (toekomstige) franchisenemer. Aldus dient deze wetgeving ter bescherming van de kandidaat-franchisenemer. De precontractuele fase van de franchiseovereenkomst kent in die gevallen dus een wettelijk kader.
* Mr. dr. S.A. Kruisinga is universitair hoofddocent bij het Molengraaff Instituut voor Privaatrecht van de Universiteit Utrecht en professional support lawyer bij Van Benthem \& Keulen. Mr. M.I. Nijenhof-Wolters is advocaat bij Van Benthem \& Keulen.
In Nederland is in het voorjaar van 2017 het conceptwetsvoorstel Wettelijke verankering gedragscode franchise ter consultatie voorgelegd. ${ }^{1}$ In deze consultatieronde zijn in totaal 359 reacties ingediend. Dit conceptwetsvoorstel is na de consultatie gestrand. Vervolgens is in het op 10 oktober 2017 gepubliceerde regeerakkoord afgesproken dat er aanvullende wetgeving komt op het gebied van franchise 'om de positie van franchisenemers (...) te versterken'.2 Aansluitend daarop heeft Mona Keijzer, staatssecretaris van Economische Zaken en Klimaat in een Kamerbrief van 23 mei 2018, mede namens de minister van Rechtsbescherming, de stand van zaken met betrekking tot regelgeving over franchise toegelicht. ${ }^{3} \mathrm{Zij}$ stelt dat het kabinet, om invulling te geven aan het voornemen uit het regeerakkoord,

'een wettelijke regeling (zal) voorbereiden die een kader schept voor vier deelgebieden van de samenwerking tussen franchisegevers en franchisenemers die cruciaal zijn voor evenwichtige franchiseverhoudingen. Dit betreft de precontractuele uitwisseling van informatie, de tussentijdse wijziging van een

1. www.internetconsultatie. $\mathrm{nl} /$ franchise/details, laatst geraadpleegd 15 april 2019. Vgl. daarover o.m. H.N. Schelhaas \& J.H.M. Spanjaard, Het wetsvoorstel franchise: better think twice!, Contracteren 2017/3, p. 105-115; M. de Koning, Het 'wettelijk haakje' van de Nederlandse Franchise Code. Handig (aan)gehaakt of toch liever zelf iets breien?, NJB 2017/967.

2. Vertrouwen in de toekomst, Regeerakkoord 2017-2021, p. 35, www. kabinetsformatie2017.nl/documenten/publicaties/2017/10/10/ regeerakkoord-vertrouwen-in-de-toekomst, laatst geraadpleegd 15 april 2019.

3. www.rijksoverheid.nl/documenten/kamerstukken/2018/05/23/ kamerbrief-stand-van-zaken-regelgeving-franchise, laatst geraadpleegd 15 april 2019. 
lopende franchiseovereenkomst, de beëindiging van de franchisesamenwerking en het overleg tussen de franchisegever en zijn franchisenemers. Op basis van de huidige inzichten lijkt het opportuun in regelgeving de genoemde deelgebieden van de nodige kaders te voorzien, in plaats van verankering via een gedragscode.'

- Op 12 december 2018 is een nieuw voorontwerp gepubliceerd en ter consultatie voorgelegd. In deze consultatieronde zijn in totaal 362 reacties ingediend. ${ }^{4}$ Wat de reactie hierop zal zijn van de verantwoordelijke minister van Rechtsbescherming en de staatssecretaris van Economische Zaken en Klimaat is ten tijde van het schrijven van deze bijdrage (april 2019) nog niet bekend. In de tussentijd zit de rechtspraak niet stil. Op 21 september 2018 wees de Hoge Raad een arrest in een zaak over een franchiseovereenkomst (hierna: het Albert Heijnarrest). ${ }^{5}$ Dit arrest sluit aan bij de eerdere rechtspraak van de Hoge Raad over franchising.

- In deze bijdrage gaan wij specifiek in op (het bestaan van) de verplichting van de franchisegever om de franchisenemer in te lichten omtrent de te verwachten omzet of omtrent de winstverwachting (par. 2 en 3). Dit doen wij aan de hand van het Albert Heijn-arrest, waar juist deze vraag het onderwerp van het geschil was (par. 4 en 5). De uitkomst van dit geschil zetten wij in deze bijdrage af tegen het conceptwetsvoorstel van 12 december 2018 (par. 6). De bijdrage wordt afgesloten met een conclusie en enkele gedachten voor de wetgever die mede zijn ontleend aan de Belgische regelgeving voor franchiseovereenkomsten, voor het geval de verantwoordelijke ministeries besluiten om, ondanks de reacties in de internetconsultatie, de tekst van het voorontwerp als uitgangspunt te nemen voor toekomstige wetgeving (par. 7 en 8). Ter zijde zij opgemerkt dat wij ons uitsluitend richten op de privaatrechtelijke aspecten van de franchiseovereenkomst.

www.internetconsultatie.nl/wet_franchise, laatst geraadpleegd 15 april 2019. Vgl. over dit voorontwerp H.N. Schelhaas \& J.H.M. Spanjaard, Het Voorontwerp Franchise: strike two voor de wetgever, Contracteren 2019/1, p. 3-14; M. de Koning, Het wetsvoorstel Franchise. Bezint eer ge begint, NJB 2019/201; A.W. Dolphijn, De (hard) franchiseovereenkomst en zorgplicht gekwalificeerd, WPNR 2019/7226, p. 100-108; J.A.M. Lambers, Franchise: posities verdraaid of verfraaid?, MvV 2019/2, p. 61-68.

5. HR 21 september 2018, ECLI:NL:HR:2018:1696, JOR 2018/321, m.nt P.G.M. Brouwer, NJ 2018/398.

\section{Rust op de franchisegever een verbintenis om de franchisenemer in te lichten omtrent de te verwachten omzet of winst?}

Uit de rechtspraak van de Hoge Raad vloeit voort dat als regel geldt dat er geen verbintenis op de franchisegever rust om voorafgaand aan de totstandkoming van de franchiseovereenkomst de franchisenemer informatie te verstrekken over de te verwachten omzet of omtrent de winstverwachting. In het arrest in de zaak Paalman/ Lampenier overwoog de Hoge Raad: ${ }^{6}$

'(u)it hetgeen redelijkheid en billijkheid eisen, in verband met de aard van de franchiseovereenkomst, vloeit niet de algemene regel voort dat op de franchisegever een verbintenis rust om de franchisenemer in te lichten omtrent de te verwachten omzet of omtrent de winstverwachting'.

De Hoge Raad voegt daaraan direct toe dat de bijzondere omstandigheden van het geval het bestaan van een zodanige verbintenis wel kunnen meebrengen. Zodanige omstandigheden heeft het hof in de zaak Paalman/Lampenier echter niet vastgesteld en daarover wordt in cassatie niet geklaagd.

Bezien vanuit het wettelijk kader bestaat er dus geen verplichting voor de franchisegever om voorafgaand aan het sluiten van de franchiseovereenkomst informatie te verstrekken aan de toekomstige franchisenemer. Het feit dát de hier besproken informatie aanwezig is, maakt dit niet anders.

Een verplichting voor de franchisegever om informatie aan de (toekomstige) franchisenemer te verstrekken, kan wel bestaan op grond van de NFC. ${ }^{7}$ De NFC is een gedragscode, opgesteld door vertegenwoordigers van franchisegevers en franchisenemers, en bevat rechten en verplichtingen voor beide partijen. De NFC is opgesteld als een vorm van zelfregulering en heeft dus geen afdwingbare juridische status. Er bestaat geen verplichting de NFC toe te passen. Op het merendeel van de franchiseovereenkomsten lijkt de NFC niet van toepassing te zijn verklaard. ${ }^{8}$ Artikel 3.4 NFC bepaalt dat de franchisegever de (toekomstige) franchisenemer 'correcte en zo volledig mogelijke schriftelijke informatie en documentatie' verstrekt 'binnen een redelijke termijn vóór het sluiten van de betreffende overeenkomst'. Uit de toelichting volgt dat aan deze informatieplicht niet

6. HR 25 januari 2002, ECLI:NL:HR:2002:AD7329, NJ 2003/31, m.nt. J.B.M. Vranken (Paalman/Lampenier), r.o. 3.3.3.

7. De NFC is te raadplegen via www.franchise.nl (Franchise van A tot Z), laatst geraadpleegd 15 april 2019.

8. Van den Berg stelde in het FD van 27 april 2017 dat de NFC in de periode van zijn lancering in februari 2016 tot het schrijven van het artikel nauwelijks van toepassing was verklaard op franchiserelaties. 
wordt voldaan 'als de franchisegever informatie waarvan hij weet of zou moeten begrijpen dat die voor de franchisenemer van belang is voor de beoordeling van de mogelijke samenwerking' niet overhandigt.

Uit artikel 3.6 aanhef en sub d NFC volgt dat de door de franchisegever te verstrekken informatie onder meer omvat 'bij voorkeur [cursivering $\mathrm{SK} \& \mathrm{MN}$ ] een zorgvuldig en transparant onderbouwde omzet- en kostenprognose, vergezeld van een vestigingsplaatsonderzoek en/of beschikbare historische cijfers, en een begrijpelijk onderbouwde en deugdelijke investerings- en exploitatiebegroting'. Het gebruik van de bewoordingen 'bij voorkeur' illustreert dat geen sprake is van een concrete verplichting, maar veeleer van een in de NFC neergelegde wens.

Ook de EEF, aanvaard door de overkoepelende Europese brancheorganisatie voor franchisegevers, bevat allerlei gedragsregels die franchisegevers en franchisenemers zouden kunnen toepassen in hun samenwerking. Deze code is in het leven geroepen om bij te dragen aan 'een efficiënt raamwerk voor franchising' waarbinnen partijen kunnen handelen. De EEF is een erecode waaraan franchisegevers die lid zijn van de Nederlandse Franchise Vereniging (NFV) zich hebben gecommitteerd. Lang niet alle franchisegevers zijn echter lid van de NFV. ${ }^{9}$ De EEF is géén wetgeving en heeft in die zin, net als de NFC, geen juridisch afdwingbare status. Artikel 4.3 EEF regelt dat de franchisegever financiële ramingen c.q. prognoses aan de franchisenemer dient te verstrekken, indien deze aanwezig zijn. Dit dient te gebeuren binnen redelijke tijd voor het sluiten van de franchiseovereenkomst. In tegenstelling tot de NFC bevat de EEF dus wel een concrete verplichting tot het verstrekken van informatie.

Samenvattend geldt dus dat, daar waar de EEF en/of de NFC geen toepassing hebben (doordat deze niet van toepassing verklaard zijn op de franchiseovereenkomst), de franchisegever niet verplicht is om de franchisenemer in te lichten omtrent de te verwachten omzet of omtrent de winstverwachting, zelfs niet daar waar deze informatie wel voorhanden is. De bijzondere omstandigheden van het geval kunnen dit anders maken.
9. Kolenbrander stelde in NJB 2014/474 dat in 2014 ongeveer $30 \%$ van alle franchiseformules in Nederland zijn aangesloten bij de NFV.

\section{In hoeverre kan de franchisegever, indien (onverplicht) informatie en overige gegevens, waaronder een omzetprognose, worden verstrekt, aansprakelijk zijn?}

In de arresten Paalman/Lampenier ${ }^{10}$ en Street-One ${ }^{11}$ is de situatie aan de orde waarin wel een omzetprognose is verstrekt. In die gevallen rees de vraag of een franchisegever onrechtmatig handelt indien hij een rapport verstrekt over de te verwachten omzet en de te verwachten winst, terwijl dit rapport fouten blijkt te bevatten.

In het arrest Paalman/Lampenier overwoog de Hoge Raad dat de franchisegever die een rapport over de te verwachten omzet en de te verwachten winst aan zijn wederpartij verschaft, onder omstandigheden onrechtmatig handelt indien hij weet dat dit rapport ernstige fouten bevat en hij zijn wederpartij niet op deze fouten opmerkzaam maakt. Het is van belang om op te merken dat het in dit geval ging om de situatie dat de franchisegever het opstellen van de omzetprognose aan een derde had uitbesteed. De Hoge Raad overwoog dat in een dergelijk geval ook de franchisegever in de regel op de juistheid van een dergelijke rapport mag vertrouwen, zodat in beginsel van onzorgvuldig handelen aan de zijde van de franchisegever pas sprake is indien hij wéét dat het rapport ernstige fouten bevat en hij zijn wederpartij niet op deze fouten opmerkzaam maakt. In de regel zal een franchisegever in een dergelijk geval niet aansprakelijk zijn als hij niet wist dat het rapport fouten bevatte, maar dit wellicht wel had kunnen weten en de franchisenemer hierover niet heeft geïnormeerd.

Ook in het Street-One-arrest gaat de Hoge Raad in op de situatie waarin wél een omzetprognose is verstrekt. In deze zaak rees de vraag of een franchisegever onrechtmatig handelt indien hij voorafgaand aan het sluiten van de franchiseovereenkomst een analyse omtrent de te verwachten omzet aan zijn wederpartij verstrekt waarvan hij niet weet, maar (slechts) behoort te weten dat die analyse fouten bevat. $\mathrm{Bij}$ het beantwoorden van deze vraag maakt de Hoge Raad een onderscheid tussen (1) de situatie dat de prognose door de franchisegever zelf is opgesteld, of door iemand voor wie hij aansprakelijk is op de voet van de artikelen 6:170-172 van het Burgerlijk Wetboek (BW), en (2) de situatie (zoals in het arrest

10. HR 25 januari 2002, ECLI:NL:HR:2002:AD7329, NJ 2003/31, m.nt. J.B.M. Vranken (Paalman/Lampenier).

11. HR 24 februari 2017, ECLI:NL:HR:2017:311, NJ 2018/12, m.nt. J.B.M Vranken (Street-One). Vgl. daarover ook M. Raas \& R.B. Musters, Franchiseprognoses volgens de zaak Street-One: aansprakelijkheid halverwege Paalman/Lampenier en de Nederlandse Franchise Code?, Contracteren 2017/3, p. 77-82. 
Paalman/Lampenier) dat de franchisegever het opstellen van de prognose aan een derde heeft uitbesteed.

In het eerste geval kan naar het oordeel van de Hoge Raad (r.o. 5.3) 'ook sprake zijn van onzorgvuldig handelen zonder dat de franchisegever (of de persoon voor wie hij aansprakelijk is) weet dat het rapport fouten bevat, en wel indien onzorgvuldigheid van de franchisegever (of van de persoon voor wie hij aansprakelijk is) heeft geleid tot de fouten in het rapport'. Dat betekent dat in het geval de franchisegever zelf, of een persoon voor wie hij aansprakelijk is op de voet van de artikelen 6:170-172 $\mathrm{BW}$, het onderzoek uitvoert en de resultaten daarvan aan zijn wederpartij (de (toekomstig) franchisenemer) verstrekt, sprake kan zijn van onzorgvuldig handelen zonder dat de franchisegever (of de persoon voor wie hij aansprakelijk is) weet dat het rapport fouten bevat, bijvoorbeeld indien onzorgvuldigheid van de franchisegever (of van de persoon voor wie hij aansprakelijk is) heeft geleid tot de fouten in het rapport. ${ }^{12}$

\section{Het Albert Heijn-arrest}

De vraag of op de franchisegever een verbintenis rust om voorafgaand aan de totstandkoming van de franchiseovereenkomst aan de (toekomstige) franchisenemer een omzetprognose te verstrekken, kwam ook aan de orde in het Albert Heijn-arrest. In de zaak die aan dit arrest ten grondslag ligt, beroept de franchisenemer zich onder meer op dwaling bij het aangaan van de franchiseovereenkomst. Hij stelt dat de franchisegever hem in de precontractuele fase, naast de verstrekte omzetprognoses, ook eerder opgestelde initiële omzetprognoses had moeten verstrekken.

Wat waren de relevante feiten? In deze zaak kwam de eigenaar van een supermarkt in Raamsdonksveer, die sinds 1998 op franchisebasis werd geëxploiteerd volgens de C1000-formule, in contact met Albert Heijn. De daarin gespecialiseerde afdeling Location Strategy van Albert Heijn deed onderzoek naar het omzetpotentieel van de supermarkt. In de wijze waarop deze afdeling haar onderzoek uitvoert, kunnen zes fasen worden onderscheiden; in elke fase wordt een omzetprognose vastgesteld. In de eerste vier fasen was de werkelijke omzet van de supermarkt in Raamsdonksveer niet bekend bij Albert Heijn. In fase 1 werd de omzet van de supermarkt als C1000-vestiging geschat op $€ 275.000$ per week. In fase 4 werd de omzet van de supermarkt als Albert Heijn-vestiging in het derde jaar na overname door Albert Heijn, op basis van onder meer theoretische benaderingen en aannames, geschat op $€ 250.000$ per week.

In fase 5 werd, na het due diligence-onderzoek dat Albert Heijn had uitgevoerd, de werkelijke weekomzet van de supermarkt als C1000-vestiging bekend. Vervolgens zijn de prognoses in fase 5 en 6 (mede) gebaseerd op de werkelijke weekomzet van $€ 300.000$. Na verbouwing is de supermarkt heropend onder de Albert Heijn-formule. De omzet loopt terug naar gemiddeld $€ 240.000$ per week in het eerste jaar en gemiddeld $€ 210.000$ in het tweede jaar. De supermarkt blijkt niet in staat de geprognosticeerde omzetten te realiseren en start een procedure. De franchisenemer beroept zich onder meer op dwaling bij het aangaan van de franchiseovereenkomst. De franchisenemer vordert een verklaring voor recht dat hij bij het aangaan van de franchiseovereenkomst heeft gedwaald en dat Albert Heijn zich schuldig heeft gemaakt aan bedrog, misbruik van omstandigheden, toerekenbaar tekortschieten en/of onrechtmatig handelen.

Albert Heijn heeft aan de franchisenemer een vestigingsplaatsadvies verstrekt en een langetermijnprognose met toelichting, die respectievelijk door de afdelingen Location Strategy van Ahold Europe en Albert Heijn zijn opgesteld. Hieraan is een uitgebreide disclaimer toegevoegd. De prognose geeft in een tabel (onder meer) de gemiddelde weekomzet weer, geprognosticeerd voor de eerste acht exploitatiejaren. In deze prognose wordt de omzet in het eerste jaar gesteld op $€ 280.000$, in het tweede jaar op $€ 295.800$ en in het derde jaar op $€$ 315.200. De bij de prognose gevoegde toelichting vermeldt ten aanzien van de geschatte omzet dat deze in het eerste jaar $€ 280.000$ en in het derde jaar $€ 300.000 \mathrm{zal}$ bedragen en dat de omzet in de prognose is opgehoogd met de jaarlijkse landelijk verwachte groei van de Albert Heijn-omzet.

De rechtbank oordeelde, onder verwijzing naar de hiervoor besproken jurisprudentie, dat geen sprake is van het bestaan van een op de franchisegever rustende verbintenis om voorafgaand aan de totstandkoming van de franchiseovereenkomst informatie te verschaffen aan de (toekomstige) franchisenemer. $\mathrm{Nu}$ in dit geval echter wel degelijk informatie is verschaft, heeft de rechtbank onderzocht of deze informatie deugdelijk was. Naar het oordeel van de rechtbank is de aan franchisenemer verstrekte prognose voor wat betreft de geprognosticeerde weekomzetten niet op basis van een zorgvuldig uitgevoerd vestigingsplaatsonderzoek opgesteld en derhalve ondeugdelijk. De rechtbank heeft voor recht verklaard dat de franchisenemer bij het aangaan van de franchiseovereenkomst met Albert Heijn heeft gedwaald. Anders dan de rechtbank oordeelde het hof dat de ondeugdelijkheid in dit geval niet kon worden aangenomen. Het hof heeft, met vernietiging van het vonnis van de rechtbank, de vorderingen van de franchisenemer afgewezen. De Hoge Raad laat dit oordeel in stand. 


\section{De overwegingen van de Hoge Raad en een analyse van het arrest}

\subsection{De overwegingen in cassatie}

In cassatie stelt de franchisenemer dat de regels zoals neergelegd in de EEF op grond van de eisen van redelijkheid en billijkheid of de maatschappelijke zorgvuldigheid met zich kunnen brengen dat een verplichting op de franchisegever rust om in de precontractuele fase alle informatie en overige gegevens te verstrekken die een franchisenemer nodig heeft om te beslissen tot het sluiten van de franchiseovereenkomst over te gaan. Volgens de franchisenemer is daartoe niet vereist dat tussen partijen is of wordt gerefereerd aan de in de EEF neergelegde normen. Voor de vaststelling van wat redelijkheid en billijkheid eisen, moeten de in de EEF neergelegde afspraken en verplichtingen worden aangemerkt als 'in Nederland levende rechtsovertuigingen' als bedoeld in artikel 3:12 BW. De franchisenemer stelt zich op het standpunt dat het hof vorenstaande heeft miskend en dat het hof ten onrechte heeft geoordeeld dat de gegeven informatie deugdelijk is.

De Hoge Raad overweegt allereerst dat op grond van hetgeen redelijkheid en billijkheid eisen, in verband met de aard van de franchiseovereenkomst, geen algemene regel geldt dat een franchisegever een franchisenemer moet inlichten omtrent de te verwachten omzet of omtrent de winstverwachting. De bijzondere omstandigheden van het geval kunnen echter wel een zodanige verplichting meebrengen. De Hoge Raad overweegt voorts dat uit 'de enkele omstandigheid dat de franchisegever bij de onderhandelingen voorafgaand aan het sluiten van de franchiseovereenkomst aan de franchisenemer een rapport over de te verwachten omzet en de te verwachten omzet heeft verschaft', niet kan worden afgeleid dat een daartoe strekkende verbintenis op de franchisegever rustte. De Hoge Raad verwijst naar het arrest Paalman/Lampenier.

Vervolgens maakt de Hoge Raad korte metten met het hiervoor genoemde standpunt van de franchisenemer door te overwegen (in r.o. 3.3.3) dat 'de in de Europese Erecode neergelegde afspraken niet zonder meer (kunnen) worden aangemerkt als "in Nederland levende rechtsovertuigingen" als bedoeld in artikel 3:12 BW'. Daarom bestaat, zo overweegt de Hoge Raad, geen grond voor de bepleite algemene verplichting van de franchisegever om in de precontractuele fase 'alle informatie en overige gegevens' aan de (toekomstige) franchisenemer te verstrekken, waaronder de initiële omzetprognose. De klacht van de franchisenemer wordt op dit punt dan ook ongegrond geacht door de Hoge Raad.

Er is ook nog een aantal klachten geformuleerd tegen de beslissing van het hof dat de omzetprognose (kort gezegd) niet ondeugdelijk was. Ook die klachten acht de
Hoge Raad, na bespreking van de arresten Paalman/ Lampenier en Street-One, ongegrond, omdat het oordeel van het hof op dit punt voldoende is gemotiveerd en in het licht van het partijdebat niet onbegrijpelijk is.

Kortom, hoewel in deze zaak werd betoogd dat er een volledige informatieplicht bestaat op grond van de EEF, oordeelde de Hoge Raad dat de EEF niet (rechtstreeks) van toepassing is. Met dit arrest wordt de eerdere jurisprudentie van de Hoge Raad, dat een franchisegever geen precontractuele informatieverplichting heeft over de te verwachten winst of omtrent de omzetverwachting, bevestigd. Interessant is om te bezien hoe deze uitspraak zich verhoudt met het voorontwerp dat op 12 december 2018 is gepubliceerd. Op deze vraag gaan wij in paragraaf 6 in.

\subsection{A-G Hartlief}

Verder is het interessant om te benoemen dat de Hoge Raad contrair gaat. A-G Hartlief ${ }^{13}$ beargumenteerde namelijk dat het arrest van het hof moest worden vernietigd:

'Het hof had moeten onderzoeken of Albert Heijn in de verstrekte prognose voldoende is ingegaan op de genoemde gezichtspunten met betrekking tot de invloed van de lokale omstandigheden op de te verwachten omzet voor [eiseres] als Albert Heijn-winkel. $\mathrm{Nu}$ het hof dit heeft nagelaten, kan zijn oordeel dat de verstrekte prognose deugdelijk is niet in stand blijven.'

In zijn conclusie staat A-G Hartlief stil bij het feit dat de genoemde gezichtspunten met betrekking tot de invloed van de lokale omstandigheden blijkens de initiële omzetinschatting een veel minder rooskleurig beeld geven over de verwachte omzet onder de Albert Heijn-formule dan de verstrekte omzetprognose schetst op basis van de werkelijke omzet met een correctiepercentage voor de eerste twee jaar in verband met de formulewisseling. De initiële inschatting gaat voor het derde jaar na de overname uit van een substantieel lagere omzet dan onder de C1000-formule. $\mathrm{Nu}$ de initiële omzetinschatting niet is verstrekt en de franchisenemer over dit gegeven ook niet is geinformeerd, concludeert A-G Hartlief dat de verstrekte omzetprognose bij die stand van zaken niet het gehele verhaal vertelt over de bij Albert Heijn bekende gegevens. Dat is volgens hem nu juist bij uitstek een situatie die dwaling kan opleveren.

Volgens A-G Hartlief had het hof daarom niet mogen volstaan met zijn oordeel dat Albert Heijn, op de wijze zoals zij heeft gedaan, in de prognose rekening mocht houden met de werkelijke weekomzetten van de C1000winkel en dat daaruit volgt dat niet kan worden vastgesteld dat de verstrekte prognose ondeugdelijk was. Het hof had naar zijn mening ook moeten onderzoeken of Albert Heijn in de verstrekte prognose voldoende is

13. Parket bij de Hoge Raad 4 mei 2018, ECLI:NL:PHR:2018:461, onderdeel 4.73 . 
ingegaan op de genoemde gezichtspunten met betrekking tot de invloed van de lokale omstandigheden op de te verwachten omzet voor de franchisenemer als Albert Heijn-winkel.

\subsection{Lidmaatschap NFV}

Iets wat niet in deze zaak naar voren komt, is het feit dat Albert Heijn erkend lid is van de NFV. ${ }^{14}$ Via dit lidmaatschap heeft Albert Heijn zich gecommitteerd aan de regels uit de EEF. Een van de criteria voor het lidmaatschap van de NFV is:

'leden-franchisegevers onderschrijven de EEF en hanteren deze gedragsregels in de praktijk'.

\section{Een ander criterium is:}

'de franchiseorganisatie biedt kandidaat-franchisenemers voldoende schriftelijke voorinformatie, zoals omschreven in de EEF'.

Graag staan wij in dit verband stil bij artikel 3:35 BW. Dit artikel bepaalt 'dat tegen hem die eens anders verklaring of gedraging, overeenkomstig de zin die hij daaraan onder de gegeven omstandigheden redelijkerwijze mocht toekennen, heeft opgevat als een door die ander tot hem gerichte verklaring van een bepaalde strekking, geen beroep kan worden gedaan op het ontbreken van een met deze verklaring overeenstemmende wil'. Zou de franchisenemer in dit geval hard hebben kunnen maken dat hij de gedraging van Albert Heijn, bestaande uit de uit hoofde van het lidmaatschap van de NFV gedane verklaring de EEF te volgen en meer specifiek 'voldoende schriftelijke voorinformatie zoals omschreven in de EEF' aan de franchisenemer aan te bieden, heeft mogen opvatten als een door Albert Heijn tot hem als franchisenemer gerichte verklaring dat Albert Heijn jegens hem de verplichtingen uit de EEF zal naleven, waardoor op grond van artikel 3:35 BW door Albert Heijn geen beroep kan worden gedaan op het ontbreken van een daartoe strekkende wil?

Dit valt te betwijfelen. Wij wijzen er in dat verband op dat voor de bepaling of er sprake is van een gerechtvaardigd vertrouwen dat de verklaring overeenstemt met de wil van degene die haar aflegt, rekening moet worden gehouden met alle omstandigheden van het geval. Bij het vaststellen van de betekenis van de verklaringen spelen de redelijkheid en billijkheid ook een rol. Gerechtvaardigd vertrouwen vereist 'goede trouw' zoals omschreven in artikel 3:11 BW. Goede trouw veronderstelt dat men naar de ware bedoelingen van de ander onderzoek doet, indien en voor zover daarvoor in de gegeven omstandigheden aanleiding bestaat. ${ }^{15}$ En juist op dat laatste zou een beroep op artikel 3:35 BW wel eens hebben kunnen stranden. pleegd 15 april 2019

15. F.M. van Cassel-van Zeeland, Groene Serie Vermogensrecht, Artikel 35. Gerechtvaardigd vertrouwen bij: Burgerlijk Wetboek Boek 3, Artikel 35.
Het feit (zie r.o. 3.4 van het hof) dat partijen in dit geval in de franchiseovereenkomst en in de correspondentie op geen enkele wijze hebben gerefereerd aan de EEF en als onvoldoende betwist bovendien vaststaat dat partijen ook niet hebben gesproken over de toepasselijkheid van de EEF, doet de vraag rijzen of wel sprake kan zijn van gerechtvaardigd vertrouwen. Het valt niet uit te sluiten dat onder deze omstandigheden zou zijn geoordeeld dat het enkele feit dat Albert Heijn lid is van de NFV, en dat een onderdeel van dat lidmaatschap het onderschrijven van de EEF is, onvoldoende is voor het aannemen van het vertrouwen bij de franchisenemer, en dat de franchisenemer, gezien de discrepantie tussen hetgeen Albert Heijn in haar relatie met de NFV heeft verklaard en hetgeen Albert Heijn en de franchisenemer hebben besproken en aan het papier hebben toevertrouwd, nader onderzoek had moeten doen, bijvoorbeeld door Albert Heijn hiernaar te vragen.

Een andere vraag die kan worden gesteld, is of de situatie, als hiervoor omschreven, dat een franchisegever lid is van de NFV (en zich in het kader van dat lidmaatschap heeft verbonden aan het naleven van de regels uit de EEF) kan worden gebruikt om te betogen dat sprake is van de in het arrest Paalman/Lampenier benoemde 'bijzondere omstandigheden van het geval die het bestaan van een zodanige verbintenis (lees: het bestaan van een verplichting om de (toekomstige) franchisenemer in te lichten omtrent de te verwachten omzet of omtrent de winstverwachting) kunnen meebrengen'.

In r.o. 3.3.3 van het Albert Heijn-arrest overweegt de Hoge Raad:

'(h)et onderdeel doet ook geen beroep op (in de feitelijke instanties aangevoerde) bijzondere omstandigheden die meebrengen dat Albert Heijn redelijkerwijs gehouden was om in de precontractuele fase niet alleen de definitieve prognose, maar ook de zogenoemde initiële prognose - waarvan Albert Heijn heeft aangevoerd dat deze slechts een tussenstap behelsde in het proces om (in fase 6) tot een definitieve prognose te komen - aan [eiseres] ter beschikking te stellen'.

De Hoge Raad is in het Albert Heijn-arrest, gezien de inhoud van het desbetreffende onderdeel van het cassatiemiddel, niet toegekomen aan de beoordeling of wellicht sprake is van bijzondere omstandigheden. Vraag blijft dus of het hiervoor genoemde argument dat de franchisegever lid is van de NFV voldoende gewicht in de schaal zou hebben gelegd om te komen tot de vereiste bijzondere omstandigheden die meebrengen dat de franchisegever verplicht is informatie te verschaffen. Wij concluderen, gebaseerd op dezelfde argumenten als ten aanzien van een beroep op artikel 3:35 BW, dat, gezien de discrepantie tussen hetgeen Albert Heijn in haar relatie met de NFV heeft verklaard en hetgeen Albert Heijn en de franchisenemer hebben besproken en aan het papier hebben toevertrouwd, de franchisenemer zich niet zomaar kan beroepen op het aanwezig zijn van 
bijzondere omstandigheden. Kortom: het valt te betwijfelen of het enkele lidmaatschap van de NFV een bijzondere omstandigheid is.

Het is vervolgens de vraag of derden, zoals de franchisenemer in het Albert Heijn-arrest, aan de afspraken tussen de NFV en Albert Heijn nog op andere wijze rechten zouden kunnen ontlenen. Hoofdregel binnen het contractenrecht is de relativiteit van de overeenkomst. Contractuele bedingen zijn slechts verbindend voor de partijen bij de desbetreffende overeenkomst en roepen voor derden geen rechten of verplichtingen in het leven. ${ }^{16}$

Hoewel partijen zich bij een overeenkomst uitsluitend jegens elkaar binden en de verbindende kracht van die overeenkomst zich in beginsel niet verder uitstrekt, maakt dit niet dat per definitie geen rechten en verplichtingen (kunnen) ontstaan in de verhouding tussen partijen bij de overeenkomst en derden. Het enkele bestaan van de overeenkomst biedt echter voor een derde onvoldoende grondslag voor het betoog dat bepaalde rechten en verplichtingen zijn ontstaan. Door de desbetreffende derde dient een andere grondslag te worden aangewezen. ${ }^{17}$

In het arrest Eneco Holding/Stichting Ronde van Nederland ${ }^{18}$ oordeelde de Hoge Raad in dat verband dat het uitgangspunt is dat overeenkomsten alleen partijen binden. Bij de beoordeling van de rechtsverhouding tussen partijen die niet in een contractuele verhouding tot elkaar staan, kan betekenis worden toegekend aan de feitelijk economische samenhang die bestaat tussen overeenkomsten waarbij zij wél partij zijn. Dit betekent echter niet dat de enkele omstandigheid dat een zodanige samenhang bestaat, steeds van belang is voor de beoordeling van de rechtsverhouding tussen de daarbij betrokken partijen. Het oordeel dat een contractueel beding doorwerkt in een daarmee samenhangende rechtsverhouding, moet specifiek worden gemotiveerd. Hiermee heeft de Hoge Raad duidelijk gemaakt dat een en ander niet al te gemakkelijk mag worden aangenomen.

Om tot doorwerking te komen van de bedingen uit de rechtsverhouding tussen de NFV en Albert Heijn in de rechtsverhouding tussen Albert Heijn en de franchisenemer kan gebruik worden gemaakt van het leerstuk van de samenhangende overeenkomsten. Volgens Tjong Tjin Tai passen overeenkomsten binnen voornoemd leerstuk indien verschillende overeenkomsten tussen verschillende partijen een zodanige mate van samenhang vertonen dat, in afwijking van het beginsel van contractuele relativiteit, gebeurtenissen in de ene contractuele rechtsverhouding ook gevolgen hebben voor een andere

16. Uitvoerig C.E. du Perron, Overeenkomst en derden: een analyse van de relativiteit van de contractswerking, (diss. Universiteit van Amsterdam), Deventer: Kluwer 1999, p. 9

17. Uitvoerig Du Perron 1999, p. 71.

18. HR 11 juli 2014, ECLI:NL:HR:2014:1627. samenhangende overeenkomst. ${ }^{19}$ Indien samenhang wordt aangenomen, ${ }^{20}$ kan de grondslag voor doorwerking gevonden worden in bijvoorbeeld de redelijkheid en billijkheid die de verhouding tussen partijen en nauw bij hun rechtsverhouding betrokken derden beheersen. ${ }^{21}$

Uit de jurisprudentie komt naar voren dat in bepaalde gevallen een uitzondering gemaakt kan worden op het beginsel dat contractuele bedingen alleen van kracht zijn tussen de handelende partijen. Daartoe zal dan echter wel voldoende rechtvaardiging moeten worden gevonden in de omstandigheden van het desbetreffende geval. Daarbij moet onder meer worden gedacht - kort samengevat - aan het op gedragingen van de derde terug te voeren vertrouwen van degene die zich op het beding beroept dat hij dit beding zal kunnen inroepen, en voorts aan de aard van de overeenkomst en van het desbetreffende beding in verband met de bijzondere relatie waarin de derde staat tot degene die zich op het beding beroept. ${ }^{22}$

Nog afgezien van het feit dat voornoemde jurisprudentie voornamelijk ingaat op de doorwerking van contractuele bedingen 'ten nadele' van de derde, waardoor de vraag rijst of de in die jurisprudentie geformuleerde regels analoog kunnen worden toegepast indien de derde de desbetreffende contractuele bedingen 'ten voordele' wil gebruiken, geldt ook hier weer dat wij ons afvragen of dit de franchisenemer een grondslag biedt die hout snijdt. De franchisenemer zou moeten kunnen laten zien dat hij aan de gedragingen van Albert Heijn, bestaande uit de uit hoofde van het lidmaatschap van de NFV gedane verklaring de EEF te volgen en meer specifiek 'voldoende schriftelijke voorinformatie, zoals omschreven in de EEF' aan de franchisenemer aan te bieden, het vertrouwen heeft mogen ontlenen dat hij zich mag beroepen op de bedingen die Albert Heijn met de NFV is overeengekomen. Zoals hiervoor reeds opgemerkt, valt dat te betwijfelen, gezien de discrepantie tussen hetgeen Albert Heijn in haar relatie met de NFV heeft verklaard en hetgeen Albert Heijn en de franchisenemer hebben besproken en aan het papier hebben toevertrouwd. Het enkele lidmaatschap van de NFV lijkt onvoldoende voor het ontstaan van het hiervoor vereiste vertrouwen.

Een andere grondslag voor doorwerking kan gevonden worden in het feit dat partijen en derden zich in hun

19. T.F.E. Tjong Tjin Tai, Meerpartijenovereenkomst en samenhangende overeenkomsten (Monografieën BW, nr. A29), Deventer: Wolters Kluwer 2019, p. 107. Vgl. ook S. van Dongen, Groepen van contracten (serie Onderneming en Recht, deel 95), Deventer: Wolters Kluwer 2016.

20. Zie daarover Tjong Tjin Tai 2019, p. 113-115. Vgl. ook Van Dongen 2016.

21. HR 25 maart 1966, NJ 1966/279 (Moffenkit); HR 7 maart 1969, ECLI:NL:HR:1969:AB7416, NJ 1969/249 (Gegaste Uien); HR 20 juni 1986, ECLI:NL:HR:1986:AD5694, NJ 1987/35 (Deka-Hanno/Citronas); Du Perron 1999, p. 99.

22. Vgl. bijv. HR 20 juni 1986, ECLI:NL:HR:1986:AD5694, NJ 1987/35 (Deka-Hanno/Citronas); HR 7 maart 1969, ECLI:NL:HR:1969:AB7416, NJ 1969/249 (Gegaste uien). 
onderlinge verhouding ten aanzien van elkaars met een overeenkomst verbonden belangen naar de normen van de maatschappelijke zorgvuldigheid of betamelijkheid hebben te gedragen. ${ }^{23}$ Over dit onderwerp schrijft Brouwer in zijn noot bij het Albert Heijn-arrest. ${ }^{24}$ Hij vraagt zich af of de uitkomst voor de franchisenemer uit het Albert Heijn-arrest wellicht anders zou zijn geweest indien de franchisenemer had betoogd dat Albert Heijn onrechtmatig handelde door in strijd te handelen met hetgeen volgens ongeschreven recht in het maatschappelijk verkeer betaamt, welk ongeschreven recht wordt ingekleurd door de onderschrijving van de EEF door Albert Heijn in het kader van haar lidmaatschap van de NFV. Brouwer geeft aan dat het te bezien valt of een dergelijk beroep de franchisenemer had geholpen. Wij sluiten hierbij aan. Het enkele feit dat Albert Heijn in haar relatie met de NFV bepaalde afspraken maakt, zal niet per definitie een onrechtmatig handelen jegens de franchisenemer (die tevens haar contractspartij is) inhouden. Ook hier zal meespelen dat er een discrepantie bestaat tussen hetgeen Albert Heijn in haar relatie met de NFV heeft verklaard en hetgeen Albert Heijn en de franchisenemer hebben besproken en aan het papier hebben toevertrouwd. Van de franchisenemer zal naar alle waarschijnlijkheid worden verwacht hier toch in enige mate onderzoek naar te hebben gedaan.

Mogelijk had de franchisenemer dus nog enkele standpunten, zoals hiervoor besproken, naar voren kunnen brengen. Of de uitkomst dan anders was geweest, valt te bezien. Dit komt enerzijds doordat het te betwijfelen valt of het enkele feit dat Albert Heijn lid is van de NFV voldoende gewicht in de schaal legt. Bovendien is het de vraag, mocht dit al voldoende gewicht in de schaal leggen, of de verplichtingen uit de EEF meebrengen dat ook de initiële prognose zou moeten worden overhandigd, zoals in het Albert Heijn-arrest onderwerp van geschil was.

\section{Het voorontwerp}

Zou de uitkomst van de zaak die ten grondslag lag aan het Albert Heijn-arrest anders zijn geweest als het hiervoor genoemde voorontwerp van 12 december 2018 kracht van wet zou hebben gehad? Dat is moeilijk te zeggen. Het voorgestelde artikel 7:913 BW bepaalt in lid 1 dat de franchisegever én de franchisenemer verplicht zijn elkaar tijdig, voor het sluiten en tijdens de duur van de franchiseovereenkomst, alle informatie te verstrekken

'waarvan ze weten of redelijkerwijs kunnen vermoeden dat deze voor de ander van belang is of kan worden met het oog op het sluiten en de uitvoering van de overeenkomst'.

23. HR 19 januari 1919, NJ 1919, p. 161 (Lindenbaum/Cohen), thans verankerd in art. 6:162 lid 2 BW.

24. P.G.M. Brouwer, annotatie bij het Albert Heijn-arrest, JOR 2018/321.
Deze bepaling bevat een voor beide partijen zeer omvangrijke verplichting tot het verstrekken van informatie. Het is denkbaar dat Albert Heijn op grond van een dergelijke regeling verplicht zou zijn geweest de initiële omzetprognose te verstrekken, zeker is dit echter niet. In ieder geval zou de centrale vraag in de procedure een andere zijn geweest. Zou deze bepaling destijds kracht van wet hebben gehad, dan zou in de procedure beslissend zijn geweest of de initiële omzetprognose informatie vormt waarvan Albert Heijn wist of redelijkerwijs kon vermoeden dat deze voor de eigenaar van de lokale supermarkt van belang was of kon worden met het oog op het sluiten van de overeenkomst.

De verplichtingen die voor partijen voortvloeien uit het voorgestelde artikel 7:913 BW zijn zeer omvangrijk en tegelijkertijd weinig concreet. De onvoldoende concretisering van de bepaling impliceert voor zowel de franchisegever als de franchisenemer een grote mate van rechtsonzekerheid. Datzelfde geldt ook voor artikel 7:915 lid 2 aanhef en sub b BW. Deze voorgestelde bepaling schrijft immers dwingendrechtelijk voor dat de franchisegever voorafgaand aan het sluiten van de franchiseovereenkomst aan de franchisenemer verstrekt: 'financiële gegevens met betrekking tot de beoogde locatie van de franchiseonderneming'.

Onduidelijk blijft wat precies wordt bedoeld met de term 'financiële gegevens'. De toelichting is uiterst summier en vermeldt uitsluitend dat het voor de franchisenemer van belang is om 'een beeld te hebben van het (...) financiële succes van de exploitatie van de betreffende franchiseformule op de beoogde locatie', terwijl de verplichting niet zover strekt dat de te verstrekken informatie een garantie moet omvatten op het behalen van een bepaalde omzet of een bepaald bedrijfsresultaat. Uit de memorie van toelichting volgt dat het de bedoeling is om bij algemene maatregel van bestuur nadere regels te stellen die de hiervoor genoemde bepalingen nader inkleuren. ${ }^{25}$ Het voorgestelde artikel 7:917 BW laat hiervoor ruimte. Zo kan per situatie worden aangegeven in welk geval welke financiële informatie moet worden verstrekt.

Hoewel Schelhaas en Spanjaard ${ }^{26}$ concluderen dat uit de memorie van toelichting bij het voorontwerp lijkt te volgen dat aan de kandidaat-franchisenemer omzetprognoses ter beschikking moeten worden gesteld, kan op basis van het voorontwerp niet met zekerheid worden gezegd welke informatie een franchisegever precies moet delen met een (aanstaande) franchisenemer. Dat betekent dat niet gezegd kan worden of de uitspraak in het Albert Heijn-arrest anders zou hebben geluid in het geval het voorontwerp wet zou zijn geweest. Dit voorbeeld illus-

25. Memorie van toelichting Wet Franchise, te raadplegen via www. internetconsultatie.nl/wet_franchise, laatst geraadpleegd 15 april 2019, p. 29.

26. Schelhaas \& Spanjaard 2019, p. 7. Zij formuleren dit, terecht, behoedzaam en stellen dat uit het ontwerpartikel 7:915 lid 2 sub b BW ‘lijkt te volgen dat (...) omzetprognoses aan de franchisenemer ter beschikking moeten worden gesteld'. 
treert welke complicaties het voorontwerp impliceert voor zowel franchisegevers als franchisenemers. Mocht dit voorontwerp wet worden, dan zal voor hen uit de voorgestelde algemene maatregel van bestuur moeten blijken welke informatie de franchisegever dient te verstrekken. Alleen het voorontwerp is ter consultatie voorgelegd. Dat de verantwoordelijke ministeries de (mogelijke) tekst van de bedoelde algemene maatregel van bestuur niet ter consultatie hebben voorgelegd, is een gemiste kans. Dit illustreert eens te meer het nadeel van de nu voorgestelde constructie. Dat is het gebrek aan democratische legitimatie.

Daarnaast blijkt niet duidelijk uit (de toelichting bij) het voorontwerp wat de consequentie is, of kan zijn, van het niet naleven van de hiervoor bedoelde informatieverplichting. Uit het voorgestelde artikel 7:921 BW volgt dat van het bij of krachtens titel 7.16 BW bepaalde niet ten nadele van de franchisenemer kan worden afgeweken. De voorgestelde regeling is dus dwingendrechtelijk van aard en strekt tot bescherming van de franchisenemer. De memorie van toelichting ${ }^{27}$ verbindt daaraan de gevolgtrekking dat 'een afwijking vernietigbaar (is) op grond van artikel 3:40, tweede lid, BW'. De memorie van toelichting noemt hierbij als voorbeeld het handelen in strijd met artikel 7:914 van het voorontwerp, waarin is bepaald dat de relevante informatie ten minste vier weken voorafgaand aan het sluiten van de franchiseovereenkomst moet worden verstrekt. Onduidelijk blijft wat het gevolg is van het niet in acht nemen van de informatieverplichting (art. 7:915 BW). De memorie van toelichting gaat hier niet uitdrukkelijk op in. Zou het niet verstrekken van de in artikel 7:915 BW bedoelde informatie ook tot gevolg hebben dat de overeenkomst vernietigbaar is op grond van artikel 3:40 lid 2 BW? Aannemelijk is in ieder geval dat een franchisenemer in een dergelijk geval een beroep zal kunnen doen op dwaling. ${ }^{28}$

\section{Een voorbeeld van regelgeving elders: België}

\subsection{Rechtsvergelijking}

Het geschil tussen Albert Heijn en de ondernemer uit Raamsdonksveer is, terecht, beoordeeld aan de hand van het toepasselijke Nederlandse recht. Zou de uitkomst van dit geding naar buitenlands recht vergelijkbaar zijn geweest? Het Belgische recht kent een wettelijke regeling die van toepassing is op de franchiseovereenkomst waarin een vrij omvangrijke informatieplicht is neergelegd voor de franchisegever. ${ }^{29}$ Ook het Franse recht kent een bepaling op grond waarvan de

27. Memorie van toelichting Wet Franchise, te raadplegen via www internetconsultatie.nl/wet_franchise, laatst geraadpleegd 15 april 2019, p. 36.

28. Vgl. ook Schelhaas \& Spanjaard 2019, p. 9.

29. Vgl. daarover bijv. J.W. Kolenbrander, Franchising. Waarom het eigenlijk best een goed idee is om van de franchiseovereenkomst een franchisegever, voorafgaand aan het sluiten van de franchiseovereenkomst, de nodige informatie dient te verstrekken aan de (kandidaat-)franchisenemer. ${ }^{30}$

\subsection{Een dwingendrechtelijke regeling in België}

Op 1 februari 2006 trad in België de zogenoemde Franchisewet in werking. ${ }^{31}$ Met ingang van 31 mei 2014 is deze wet met een aantal wijzigingen opgenomen in het Wetboek van economisch recht (Wer). ${ }^{32}$ Artikel X.27 Wer bepaalt dat de franchisegever voorafgaand aan het sluiten van een franchiseovereenkomst de nodige informatie dient te verstrekken aan de beoogde franchisenemer. Deze informatie dient minstens één maand voor het sluiten van de franchiseovereenkomst te worden verstrekt. Het Nederlandse voorontwerp van de Wet Franchise kent een vergelijkbare regeling in het voorgestelde artikel 7:914 BW, op grond waarvan de franchisegever de voorgeschreven informatie ten minste vier weken voor het sluiten van de franchiseovereenkomst dient te verstrekken. De wettelijke regeling in België is (net als de voorgestelde Nederlandse regeling) dwingendrechtelijk van aard, zo volgt uit artikel X.26 Wer.

Ook in België heeft de wetgever geworsteld met het vinden van een balans tussen de contractsvrijheid aan de ene kant en de bescherming van de franchisenemer aan de andere kant. De Belgische regeling doet geen afbreuk aan de contractsvrijheid, nu enkel de uitwisseling van informatie voorafgaand aan het sluiten van de overeenkomst is verbeterd. In België is enkel de precontractuele fase van de franchiseovereenkomst geregeld, nu juist in die fase het 'onevenwicht' tussen partijen bestaat, of kan bestaan. ${ }^{33}$ Wettelijk is bepaald welke informatie moet worden verstrekt, zodat de franchiseovereenkomst met kennis van zaken kan worden gesloten. De wetgever is zich bewust dat een te strikte regeling voor de franchiseovereenkomst mogelijke investeerders zou afschrikken, zeker als zij in andere landen met minder verplichtingen worden geconfronteerd.

benoemde overeenkomst te maken, NJB 2013/2302; Schelhaas \& Spanjaard 2019; Lambers 2019, p. 64-66.

30. Art. L330-3 van de Franse Code de Commerce bepaalt dat de franchisegever ten minste twintig dagen voor de ondertekening van de franchiseovereenkomst aan de (kandidaat-)franchisenemer een document dient te verstrekken, waarvan de inhoud bij besluit is vastgelegd. In dit document dienen o.m. de staat en vooruitzichten van de ontwikkeling van de betrokken markt te worden aangeduid, en de duur van de overeenkomst, de voorwaarden voor verlenging en beëindiging van de overeenkomst en de exclusiviteitsbepalingen. Vgl. ook I.S.J. Houben, J. Sterk \& J.A.J. Devilee, Codificatie of zelfregulering in de franchisesector?, MvV 2014/9, p. 243-244.

31. Wet van 19 december 2005 betreffende de precontractuele informatie bij commerciële samenwerkingsovereenkomsten, BS 18 januari 2006 en err. BS 13 februari 2006. Vgl. daarover ook J.H.M. Spanjaard, Dwalen over franchise, Contracteren 2017/3, p. 97-98.

32. Vgl. M.J.M. Vromans, Franchising in België: ervaringen met de Belgische 'Franchisewet', Franchise \& Recht informatiebron 2015/1, p. 10. De relevante wetgeving is te raadplegen via www.ejustice.just.fgov.be/ cgi_loi/change_lg.pl?language $=$ nl\&la $=$ N\&cn=2014040221\&table_ name=wet, laatst geraadpleegd op 15 april 2019.

33. B. Ponet, De wet betreffende de precontractuele informatie bij commerciële samenwerkingsovereenkomsten: zes jaar toepassing in de praktijk, Rechtskundig Weekblad 2012-13/5, p. 164 
Dit is treffend verwoord in de parlementaire stukken:

'(d)e ontwikkeling van commerciële formules die hun nut hebben bewezen in België, in Europa en op wereldvlak mag niet worden afgeremd. Door deze vormen van commerciële formules te strikt en te strak te regelen, zou België zich isoleren binnen de Europese Unie en zou dit buiten- en binnenlandse investeerders die in andere landen met minder verplichtingen worden geconfronteerd, ontmoedigen. (...) Een wetgevende tekst die een verplichting tot precontractuele informatie bevat voor dergelijke vormen van overeenkomst is dus nuttig, terwijl tezelfdertijd het risico van een te strikte en te gedetailleerde wetgeving wordt vermeden die de vrijheid van ondernemen aantast. $^{34}$

\subsection{Welke gegevens dient de franchisegever naar Belgisch recht te verstrekken?}

Uit artikel X.27 Wer vloeit voort dat de franchisegever een ontwerp van de overeenkomst dient te verstrekken én een afzonderlijk document. Dit laatste document dient niet alleen de belangrijke bepalingen uit de franchiseovereenkomst te bevatten, maar ook gegevens voor de correcte beoordeling van de - nog te sluiten franchiseovereenkomst. Deze informatie dient schriftelijk of op een voor de beoogde franchisenemer duurzame en toegankelijke drager ter beschikking te worden gesteld. Het afzonderlijke document dat moet worden verstrekt, wordt ook wel aangeduid als het afzonderlijk document inzake precontractuele informatie (DPI).

De wet bepaalt dat het afzonderlijke document de belangrijke contractuele bepalingen uit de franchiseovereenkomst dient te bevatten, waaronder de verbintenissen (art. X.28 par. 1 sub b Wer), de gevolgen van het niet behalen van de verbintenissen (art. X.28 par. 1 sub c Wer), de rechtstreekse vergoeding die de beoogde franchisenemer moet betalen aan de franchisegever en de berekeningswijze voor de onrechtstreekse vergoeding die de franchisegever ontvangt en, in voorkomend geval, de wijze van herziening in de loop van de overeenkomst en bij de hernieuwing ervan (art. X.28 par. 1 sub d Wer), de concurrentiebedingen, hun duur en hun voorwaarden (art. X.28 par. 1 sub e Wer), de duur van de commerciële samenwerkingsovereenkomst en de voorwaarden voor de hernieuwing (art. X.28 par. 1 sub $\mathrm{f}$ Wer), de voorwaarden voor opzegging en beëindiging van de overeenkomst met name wat de lasten en de investeringen betreft (art. X.28 par. 1 sub g Wer), de voorkooprechten of de aankoopoptie ten voordele van de franchisegever en de regels voor de waardebepaling van de handelszaak bij de uitoefening van deze rechten of deze optie (art. X.28 par. 1 sub h Wer), en de exclusivi-

34. Belgische Kamer van Volksvertegenwoordigers, 1 juli 2005, Wetsontwerp betreffende de precontractuele informatie bij commerciële samenwerkingsovereenkomsten, Doc 51, 1687/005, 2004/2005, 3e zitting van de 51e zittingsperiode, p. 5, te raadplegen via www.dekamer.be/ FLWB/pdf/51/1687/51K1687005.pdf, laatst geraadpleegd 16 april 2019. teit die is voorbehouden aan de franchisegever (art. X.28 par. 1 sub i Wer).

Daarnaast dient de franchisegever op grond van artikel X.28 par. 1 sub 2 Wer gegevens te verstrekken voor de correcte beoordeling van de franchiseovereenkomst op grond van artikel X.28 par. 1 sub 2 Wer. Op grond van deze bepaling zijn dit onder meer de volgende gegevens: (...)

e. in voorkomend geval de jaarrekeningen van de laatste drie boekjaren van de franchisegever;

f. de ervaring met franchising en de ervaring binnen de exploitatie van de franchiseformule buiten een franchiseovereenkomst;

g. de historie, de staat en de vooruitzichten van de markt waarin de activiteiten worden uitgeoefend, vanuit algemeen en lokaal oogpunt;

h. de historie, de staat en de vooruitzichten van het marktaandeel van het netwerk vanuit een algemeen en lokaal oogpunt;

i. in voorkomend geval voor elk van de voorbije drie jaren het aantal uitbaters dat deel uitmaakt van het Belgische en internationale netwerk, alsook de expansievooruitzichten van het netwerk;

j. in voorkomend geval voor elk van de voorbije drie jaren het aantal franchiseovereenkomsten dat is afgesloten, het aantal franchiseovereenkomsten dat is beëindigd op initiatief van de franchisegever en op initiatief van de franchisenemer, evenals het aantal franchiseovereenkomsten dat niet werd hernieuwd op de vervaldag;

k. de lasten en investeringen waartoe de franchisenemer zich verbindt bij de aanvang en tijdens de looptijd van de franchiseovereenkomst, met opgave van de bedragen en hun bestemming alsook hun aflossingstermijn, het ogenblik waarop ze aangegaan zullen worden en hun lot bij beëindiging van de overeenkomst.

Een specifieke marktstudie is niet vereist. Met een marktstudie wordt niet bedoeld een voorstelling van de markt. Met een marktstudie wordt een analyse van de gegevens over het mogelijke klantenbestand bedoeld. ${ }^{35}$ Op grond van de hiervoor besproken bepaling is het dus naar Belgisch recht niet vereist om een (kandidaat-)franchisenemer in te lichten omtrent de te verwachten omzet of omtrent de winstverwachting. De franchisenemer draagt immers zelf het ondernemersrisico. De overdracht van informatie die de wet voorschrijft, in combinatie met de hierna te bespreken bedenktijd (ook wel cooling off-periode genoemd), heeft juist als doel om de franchisenemer de tijd en de benodigde informatie te verstrekken om zelf een analyse te (laten) maken. De franchisegever kan volstaan met het meedelen van hem bekende objectieve gegevens. Indien hij, bijvoorbeeld, weet van de komst van een concurrerende speler op de relevante markt, kan hij dat niet ver-

35. Vgl. S. Claeys, Franchising. Tussen zelfstandigheid en afhankelijkheid: een onevenwichtige samenwerking? (diss. KU Leuven), 2009, p. 308-309. 
zwijgen, maar hij is niet gehouden om een specifieke analyse te geven van de gevolgen hiervan voor de resultaten. 36

\subsection{Latere wijziging van de overeenkomst}

Ook voor een latere wijziging in de overeenkomst of in het DPI geldt opnieuw de genoemde termijn van één maand. Wordt in het ontwerp van de overeenkomst of in het afzonderlijke document, nadat dit aan de beoogde franchisenemer is verstrekt, een wijziging aangebracht, dan verstrekt de franchisegever, minstens één maand voor het sluiten van de franchiseovereenkomst, aan de beoogde franchisenemer het gewijzigde ontwerp van overeenkomst en een vereenvoudigd afzonderlijk document. Deze termijn van een maand wordt ook wel een cooling off-periode genoemd. Gedurende deze termijn mag in beginsel geen andere verbintenis worden aangegaan en mag geen andere vergoeding, bedrag of waarborg worden gevraagd of betaald. Deze termijn behoeft overigens niet in acht te worden genomen indien de wijziging schriftelijk werd aangevraagd door de beoogde franchisenemer.

Vrijwel dezelfde informatie moet ook worden verstrekt in geval van verlenging van een franchiseovereenkomst die is gesloten voor een bepaalde tijd, in geval van het sluiten van een nieuwe franchiseovereenkomst tussen dezelfde partijen, of in geval van een wijziging van een bestaande franchiseovereenkomst; ook daarvoor geldt in de regel de genoemde termijn van één maand vóór de verlenging of wijziging van de overeenkomst of het sluiten van de overeenkomst (art. X.29 Wer), zij het dat volstaan kan worden met een vereenvoudigd document.

Dit is anders in het Nederlandse voorontwerp van de Wet Franchise. Het voorgestelde artikel 7:914 BW bepaalt dat de relevante informatie ten minste vier weken voor het sluiten van de franchiseovereenkomst dient te worden verstrekt. Dit geldt echter, op grond van het voorgestelde artikel 7:914 lid $3 \mathrm{BW}$, niet voor wijzigingen van een bestaande franchiseovereenkomst of voor het sluiten van een opvolgende franchiseovereenkomst tussen dezelfde partijen inzake dezelfde franchiseformule. Het voorgestelde artikel 7:919 lid 4 BW kent een regeling voor de vraag op welke wijze een wijziging van de franchiseovereenkomst die aanzienlijke gevolgen heeft voor de exploitatie van de formule door de franchisenemer tot stand kan worden gebracht. ${ }^{37}$ Het voorontwerp volstaat met de verplichting in het voorgestelde artikel 7:916 lid 2 sub a BW, op grond waarvan de franchisegever informatie dient te verstrekken aan de franchisenemer over beoogde wijzigingen in de franchiseovereenkomst. Hier ontbreekt echter een specifieke informatieverplichting voor de franchisegever en een daarvoor te stellen termijn.

36. Claeys 2009, p. 308-309.

37. Vgl. daarover A.W. Dolphijn, De franchisenemersvereniging en de binding van franchisenemers, Contracteren 2019/1, p. 25-31.
7.5 Wat geldt in geval van niet-naleving van de verplichtingen in de Belgische regelgeving?

In geval van niet-naleving van (een van) de bepalingen in de artikelen X.27 en X.29 Wer kan de franchisenemer, binnen twee jaar na het sluiten van de overeenkomst, de nietigheid van de franchiseovereenkomst inroepen op grond van artikel X.30 Wer. ${ }^{38}$ Hiervoor is niet meer vereist dan louter niet-nakoming. Hij hoeft dus, bijvoorbeeld, niet de bijkomende vereisten voor een wilsgebrek te bewijzen. Voordat deze termijn van twee jaar is verstreken, is geen zogenoemde dekking van de nietigheid mogelijk voor wat de partijen vrijwillig uitvoeren. ${ }^{39}$ De nietigheid mag overigens geen bron van verrijking zijn; het gaat om het zo goed mogelijk terugbrengen van de partijen in de toestand vóór het sluiten van de franchiseovereenkomst. ${ }^{40}$ Voor het op rechtsgeldige wijze 'inroepen' van de nietigheid geldt geen vormvereiste: een buitengerechtelijk beroep op de nietigheid volstaat. Ontbreekt een van de in de artikelen X.28 par. 1 sub 1 en in artikel X.29 lid 2 Wer bedoelde gegevens, dan kan de franchisenemer de nietigheid van de desbetreffende bepalingen van de franchiseovereenkomst inroepen. $\mathrm{Nu}$ geen termijn is bepaald waarbinnen deze relatieve nietigheid dient te worden ingeroepen, geldt hiervoor de algemene verjaringstermijn van tien jaar; dergelijke nietigheid kan bovendien worden geheeld door vrijwillige uitvoering. ${ }^{41}$ Wanneer een van de in artikel X.28 par. 1 sub 2 en artikel X.29 lid 2 sub 2 Wer bedoelde gegevens ontbreekt, onvolledig of onjuist is, of wanneer een van de gegevens bedoeld in artikel X.28 par. 1 sub 1 en X.29 lid 2 sub 1 Wer onvolledig of onjuist is, kan de franchisenemer een beroep doen op een van de wilsgebreken (dwaling of bedrog) of op onrechtmatige daad.

\subsection{Overige relevante bepalingen in de Wer}

De Belgische wetgever was zich duidelijk bewust dat de informatie die de franchisegever dient te verstrekken (deels) concurrentiegevoelige informatie kan betreffen. Daarom bepaalt artikel X.31 Wer expliciet dat de relevante personen gehouden zijn tot geheimhouding 'met betrekking tot de inlichtingen die zij verkrijgen met het oog op het sluiten van' een franchiseovereenkomst. Zij mogen deze inlichtingen slechts gebruiken binnen de te sluiten franchiseovereenkomst.

38. Deze termijn is geen verjaringstermijn, vgl. Hof van Cassatie 12 mei 2016, RW 2016-17/38, p. 1. Bovendien werd in een eerdere procedure al geoordeeld dat het feit dat de franchisenemer (met kennis van zaken over de schending van de informatieplicht) uitvoering heeft gegeven aan de franchiseovereenkomst niet betekent dat de franchisenemer daarmee de nietigheid heeft bevestigd, dat wil zeggen afstand heeft gedaan van de mogelijkheid om zich op de geboden bescherming te kunnen beroepen. Ook een franchisenemer die uitvoering heeft gegeven aan de franchiseovereenkomst kan dus nog op een later moment, mits binnen de hiervoor genoemde termijn van twee jaar, de nietigheid van de franchiseovereenkomst inroepen vanwege schending van de informatieplicht door de franchisegever; vgl. Hof van Cassatie 17 september 2015, RW 2016-17/18, p. 699-705, m.nt. F. Peeraer.

39. Ponet 2012, p. 168.

40. Hof van Beroep Gent 18 november 2013, RW 2013-14/30 p. $1185-1187$.

41. Ponet 2012, p. 168 
De Belgische regeling stelt bovendien voorop dat de (toekomstige) franchisenemer zich in een economische zwakkere positie bevindt. Mede daarom is in artikel X.32 Wer bepaald dat de bedingen in de franchiseovereenkomst en de gegevens in het afzonderlijke document, bedoeld in artikel X.28 Wer, 'duidelijk en begrijpelijk' worden opgesteld. In geval van twijfel over de betekenis van een beding of een gegeven prevaleert de voor de franchisenemer gunstigste interpretatie.

Dit is een variant van de zogenoemde contra proferentem-regel, die is gebaseerd op het uitgangspunt dat de partij die een beding heeft opgesteld, of heeft toegevoegd aan de overeenkomst, het risico moet dragen van een eventuele onduidelijkheid in dat beding. Op grond van deze regel kan een onduidelijkheid in een contractuele clausule worden uitgelegd in het nadeel van de opsteller ervan. Voor de franchiseovereenkomst geldt naar Belgisch recht echter a fortiori dat in geval van twijfel over de betekenis van een beding in een franchiseovereenkomst de voor de franchisenemer gunstigste interpretatie hoe dan ook prevaleert, zelfs als de franchisenemer het beding zelf heeft opgesteld. ${ }^{42}$ Naar Nederlands recht geldt de contra proferentem-regel uitsluitend als gezichtspunt bij de uitleg van een overeenkomst. $^{43}$

\subsection{Suggesties voor de Nederlandse wetgever}

Wat direct opvalt in deze regelgeving is dat vrij concreet is bepaald welke informatie de franchisegever dient te overhandigen aan een (toekomstige) franchisenemer. Dit biedt rechtszekerheid voor partijen. Mochten de verantwoordelijke ministeries voortgaan met het voorbereiden van wetgeving voor de franchiseovereenkomst, dan hopen wij dat deze regelgeving een bron van inspiratie kan vormen. Wellicht is het de bedoeling om in de eerdergenoemde algemene maatregel van bestuur, waarin invulling kan worden gegeven aan de voorgestelde bepalingen in de artikelen 7:913 en 7:915 BW, ook dergelijke concreet geformuleerde bepalingen op te nemen. Of dat zo is, is op dit moment echter (nog) niet bekend, nu uitsluitend het voorontwerp als zodanig ter consultatie is voorgelegd. Overigens vragen wij ons af waarom dergelijke bepalingen niet, in navolging van de Belgische regeling, ook in de Nederlandse wet zouden kunnen worden opgenomen.

De vraag rijst of een franchisegever verplicht zou moeten zijn om voorafgaand aan het sluiten van de franchiseovereenkomst aan de (kandidaat-)franchisenemer een prognose te verstrekken omtrent de te verwachten omzet of de winstverwachting. Wij betwijfelen of dit nodig is. Vooropstaat dat naar Belgisch recht een dergelijke verplichting niet bestaat, terwijl de informatie die de franchisegever moet aanleveren wel een bron van informatie voor de (kandidaat-)franchisenemer vormt op

42. Vgl. Claeys 2009, p. 310-311.

43. Vgl. H.N. Schelhaas \& W.L. Valk, Uitleg van rechtshandelingen, in: Preadviezen uitgebracht voor de Vereniging voor Burgerlijk Recht, Zutphen: Uitgeverij Paris 2016, p. 139-140. basis waarvan hij zelf een analyse kan maken. Wij vragen ons bovendien af of een (kandidaat-)franchisenemer met een dergelijke verplichting voor de franchisegever tot het verstrekken van een prognose daadwerkelijk gebaat is. Uit de rechtspraak volgt immers dat een vordering van een franchisenemer, bijvoorbeeld op grond van dwaling of onrechtmatige daad, in verband met de verstrekte prognose zelden slaagt. ${ }^{44}$ Het uitgangspunt van de Belgische wetgeving voor de franchiseovereenkomst is juist dat de franchisegever objectieve informatie verstrekt aan de kandidaat-franchisenemer, zodat laatstgenoemde zelf een analyse kan maken en op basis daarvan kan besluiten om, al dan niet, over te gaan tot het sluiten van de franchiseovereenkomst.

De in de Belgische wetgeving opgenomen verplichting tot geheimhouding ontbreekt in het Nederlandse voorontwerp. Nu de door de franchisegever te verstrekken informatie (deels) concurrentiegevoelige informatie betreft, verdient het aanbeveling om in de Nederlandse regeling ook een dergelijk beding op te nemen. Hoewel het partijen vanzelfsprekend vrijstaat om zelf hiervoor een regeling te treffen, is er onzes inziens alle aanleiding om juist ook de franchisegever in dit opzicht tegemoet te komen, teneinde ook deze partij voldoende bescherming te bieden voor het geval een (bijvoorbeeld kleinere) franchisegever heeft nagelaten om dergelijke geheimhouding te bedingen.

Het Nederlandse voorontwerp gaat er, zo volgt uit pagina 1 van de memorie van toelichting, uitdrukkelijk van uit dat er in de franchiserelatie 'van nature een zeker overwicht bestaat bij de franchisegever ten opzichte van de franchisenemer'. De franchiserelatie is dus in zekere zin 'intrinsiek ongelijkwaardig'. Als de wetgever dit standpunt handhaaft, ligt het voor de hand om ook aansluiting te zoeken bij de contra proferentem-regeling in de Belgische wet, op grond waarvan in geval van twijfel over de betekenis van een beding de uitleg prevaleert die voor de franchisenemer het meest gunstig is.

\section{Conclusie}

In het Albert Heijn-arrest heeft de Hoge Raad opnieuw bevestigd dat naar huidig Nederlands recht geen algemene regel geldt dat een franchisegever een (toekomstige) franchisenemer moet inlichten omtrent de te verwachten omzet of omtrent de winstverwachting. De

44. Vgl. bijv. recentelijk Hof Den Bosch 5 juni 2018, ECLI:NL:GHSHE: 2018:2370; Hof Arnhem-Leeuwarden 5 februari 2019, ECLI:NL:GHARL:2019:1024. Vgl. ook J.H. Kolenbrander, De 'prognoseproblematie' revisited: een korte bespreking van jurisprudentie aangaande de zorgplicht van de franchisegever, Contracteren 2012/4, p. 159-162; A.M.A. Schwegler, De zorgplicht van de franchisegever: bijzonder of niet?, Contracteren 2016/1, p. 3-9. Het door ons gemaakte onderscheid sluit aan bij de heldere analyse die Schwegler geeft op p. 7, waar zij onderscheid maakt, voor een vordering op grond van dwaling of onrechtmatige daad, tussen het verstrekken van een prognose en het verstrekken van informatie waarop de prognose gebaseerd is. 
bijzondere omstandigheden van het geval kunnen echter wel een zodanige verplichting meebrengen. De vraag rijst of het enkele feit dat een franchisegever lid is van de NFV, en dat een onderdeel van dat lidmaatschap het onderschrijven van de EEF is, voldoende is voor het aannemen van doorwerking van de afspraken tussen de NFV en Albert Heijn in de rechtsverhouding tussen Albert Heijn en de franchisenemer. Het valt te betwijfelen of dit gegeven alleen maakt dat sprake is van de, voor het aannemen van doorwerking van contractuele bedingen, vereiste 'voldoende rechtvaardiging' c.q. 'specifieke motivering'.

Het valt op dat in het voorontwerp van de Wet Franchise een duidelijk andere benadering is gekozen. Daarin wordt immers voorgesteld een - vrij ruim geformuleerde - informatieplicht voor de franchisegever te introduceren. Welke informatie op basis daarvan door een franchisegever dient te worden verstrekt, is nog niet helder, nu het voorontwerp van wet de ruimte laat om bij algemene maatregel van bestuur nader invulling te geven aan deze verplichting. Aan de hand van voorbeelden uit de regelgeving voor de franchiseovereenkomst in België hebben wij geillustreerd dat het mogelijk is om vrij specifiek en concreet in de wet te bepalen welke (objectieve) informatie een franchisegever dient te verstrekken aan een (toekomstig) franchisenemer. Wij hopen dat de betrokken ministeries, indien besloten wordt om een wetsvoorstel in te dienen bij de Tweede Kamer, al dan niet op basis van het ter consultatie voorgelegde voorontwerp, inspiratie zullen putten uit rechtsvergelijkend onderzoek voor het aanpassen c.q. aanvullen van het voorontwerp van de Wet Franchise.

Dat het opstellen van regelgeving voor de franchiseovereenkomst overigens geen sinecure is, volgt uit het rechtsvergelijkend onderzoek van Abell. Hij vergeleek de regelgeving voor de franchiseovereenkomst in de verschillenden landen in de Europese Unie en ging na hoeveel tijd gemoeid was met het opstellen van de relevante wetgeving in de verschillende landen. ${ }^{45}$ Abell concludeert:

'It took seven years and eight bills in Italy, 24 years and five bills in Belgium and 19 years and 12 bills in Sweden to produce a franchise law.'

Nederland blijkt dan nog maar een beginneling, met een wetgevingstraject van nog geen twee jaar en twee voorontwerpen. 